\section{An unusual outcome for fetal death in bitch: a case report}

\section{Köpek fetal ölümlerinde nadir bir durum: Olgu sunumu}

\section{ABSTRACT}

In this report, an unusual condition of fetal maceration conveyed with retention of fetal debris was diagnosed 5-months after breeding in a hound bitch. A five-year-old, $13 \mathrm{~kg}$ weighted bitch was brought to Adnan Menderes University Animal Hospital with complaints of loss of appetite and abdominal distention, five months after breeding. Although presenting a distended abdomen and mammary glands, no signs of parturition have been reported. At surgery, a reddish free intra-abdominal fluid was suctioned, and hysterectomy was performed; ovaries were not excised to avoid any compromise of hunting performance. Fur and bone remnants floating in a brown-green, mucous and odorless fluid were detected at inspection of the uterus. In this case, the evaluation of the uterus showed that all the fetuses underwent maceration and autolysis at least 3 months after the pregnancy putative. Although it was seen that compatible with chronic uterine inflammation findings (leukocytosis and anemia), closed cervical position and odorless uterine content may be an unusual sequel to canine fetal death. Keywords: Fetal maceration, clinical findings, bitch.

\section{ÖZET}

$\mathrm{Bu}$ raporda bir av köpeğinde çiftleşmeden 5 ay sonra görülen fetal kalıntı tutulumlu, farklı formdaki fetal maserasyon olgusu sunulmuştur. Beş yaşl1, $13 \mathrm{~kg}$ ağırlı̆̆ındaki av köpeği çiftleştikten 5 ay sonra gözlenen iştahsızlık ve karında şişkinlik nedeni ile Adnan Menderes Üniversitesi Hayvan Hastanesi'ne getirildi. Karın ve meme bezlerinde büyüme görülmesine karşın, doğum belirtilerine rastlanmadığı kaydedildi. Operasyonda, batın içinde gözlenen kırmızımsı serbest sıv1 $(1,8 \mathrm{~L})$ aspire edildi, histerektomi yapıldı ancak av performansının etkilenmemesi için ovaryumlar bırakıldı. Uterusun inspeksiyonunda kahverengi-yeşil, muköz ve kokusuz sıvı içerisinde yüzen kemik ve tüy kalıntıları görüldü. Bu olguda, uterus incelemeleri sonucu beklenen gebeliğin başlangıcından en az 3 ay içinde tüm fetüslerin maserasyon ve otolize uğradığını göstermiştir. Kronik uterus yangısı ile uyumlu bulgular (leukositozis ve anemi) görülmesine karşın, kapalı serviks ve kokusuz uterus içeriği köpeklerdeki yavru ölümlerinde nadir görülen bir sekel olarak değerlendirilebilir

Anahtar kelimeler: Fetal maserasyon, klinik bulgular, köpek

\section{INTRODUCTION}

The follow-up of fetal mortality has variations in companion animals including mummification, maceration, partial and complete abortion (Romagnoli, 2002). Fetal maceration is rare in bitches and results from the failure of the expulsion of the aborted fetus (Johnston et al., 2001).

The delaying of death fetal delivery which is related to uterus inertia causes uterine bacterial invasion from open cervical canal. This bacterial invasion causes fluid softening, autolysis, and maceration process to occur in fetal soft tissues and fetal bones float in uterine lumen (Johnston et al., 2001). Due to limited studies (Gill, 2001; Tønnessen et al., 2012) the knowledge on canine fetal maceration is based on sporadically case presentations (Max et al., 2015).

\section{How to cite this article}

Güneş, E., Akkuş, T., Payan-Carreira, R. (2019). An unusual outcome for fetal death in bitch: a case report. J Adv VetBio Sci Tech. 4(1): 22-25. DOI: http://doi.org/10.31797/vetbio.506367
Review

Güneş Erdoğan ${ }^{1}$ Tuğra Akkuş ${ }^{2}$ Rita Payan-Carreira ${ }^{3}$

${ }^{1}$ Aydin Adnan Menderes University, Faculty of Veterinary Medicine, Department of Obstetrics and Gynecology, Aydın, Turkey ORCID: 0000-0002-9807-810X

${ }^{2}$ Harran University, Faculty of Veterinary Medicine, Department of Obstetrics and Gynecology, Şanlıurfa, Turkey ORCID: 0000-0002-6002-5942

${ }^{3}$ CECAV, Universidade de Trás-os-

Montes e Alto Douro, Vila Real, Portugal ORCID:-0000-0001-5225-4510

$\begin{array}{r}\text { Correspondence } \\ \text { Tuğra Akkuş }\end{array}$
tugraakkus08@ hotmail.com
Tel: 0(414)3183000

Article info

Submission: 01-01-2019

Accepted: 08-04-2019

Online published: 28-04-2019

This work is licensed under a Creative Commons Attribution 4.0 International License (c) $\underset{\mathrm{EY}}{\mathrm{B}}$

e-ISSN: $2548-1150$ website: http://dergipark.gov.tr/vetbio doi prefix: $\underline{10.31797 / v e t b i o .}$ 
$\mathrm{M}$ oreover, in the majority of cases the absence of general symptoms in the mother leads to misinterpretation of the diagnosis. (Gill, 2001). Fetal death symptoms and patient's prognosis are variable in dogs. Browngreenish colored vaginal discharge, depression, and general findings are frequently seen at the putative parturition date (Jones et al., 1997; England, 1998; Linda-Forsberg, 1998; Johnston et al., 2001; Jackson, 2004; Fasulkov et al., 2014), however, there are some cases recorded without any systemic findings (Serin and Parin, 2009; Sagar et al., 2017).

In this case report, a different form of fetal maceration with the fetal tissue retention seen in five months after mating is described with perioperative clinical findings.

\section{CASE HISTORY}

A five years old female hound weighing $13 \mathrm{~kg}$ was referred for examination at the Animal Hospital of Adnan Menderes University with loss of the appetite for last three days, and also abdominal distention seen five months after breeding. The owner reported there had been distension on the belly and mammary glands, but no signs of parturition during this stage. The abdomen was mildly enlarged and abdominal palpation revealed fluctuation not accompanied by pain and fetal bump on palpation (Figure 1). Her temperature was $38.9^{\circ} \mathrm{C}$, and pulsation was normal. The hematological exams showed leukocytosis (WBC: $25.10 \times 103 / \mu 1$ ) and anemia (RBC: $4.30 \times 10^{3} \%$ $\mu 1)$ while the other blood counts and biochemical parameters were within reference values.

Transabdominal ultrasound revealed hypoechoic fluid in the abdomen and hyperechoic fluid in the enlarged uterus (Figure 2). Abdominal radiography revealed small radiopaque masses consistent with fetal bones.

This case was diagnosed as fetal loss with fetal debris and medial celiotomy was performed. At surgery, reddish free intra-abdominal fluid $(1.8 \mathrm{~L})$ was suctioned, and hysterectomy was performed (Figure 3); ovaries were not excised to avoid any compromise of hunting performance. Fur and bone remnants floating in a brown-green, mucous and odorless fluid were detected at inspection of the uterus (Figure 4). The abdomen washed with sterile warm saline and closed with simple continuously absorbable sutures.

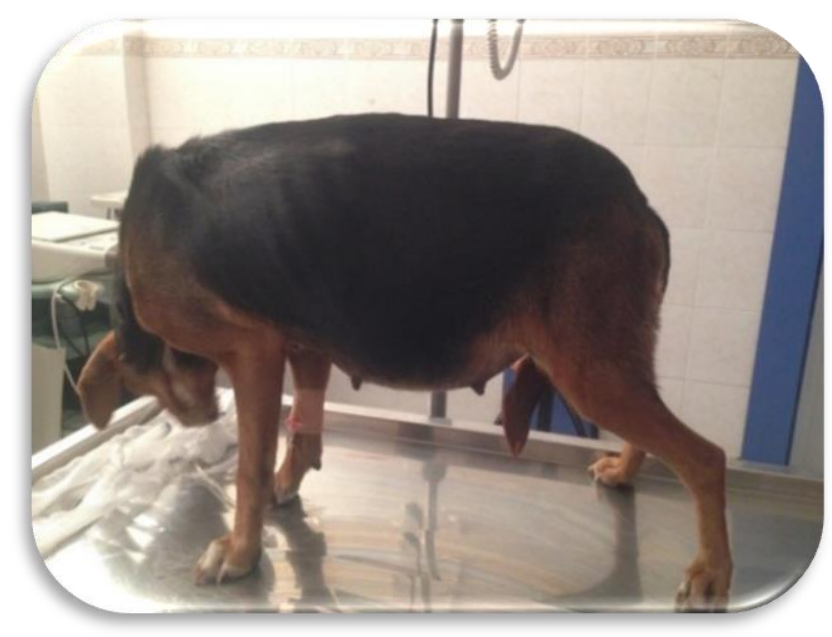

Figure 1. Mild abdominal distention

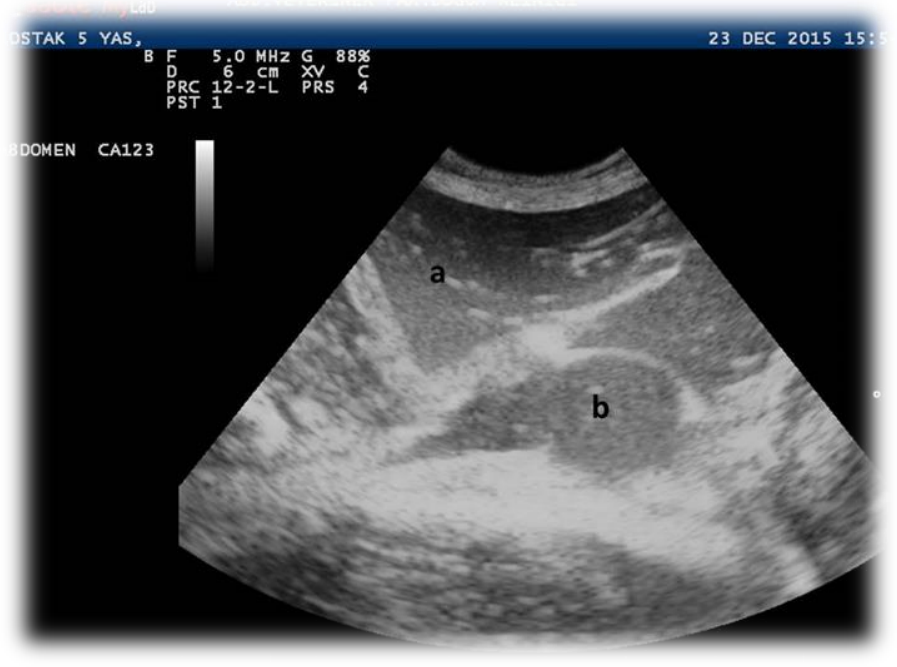

Figure 2. Intraabdominal (a) and intrauterine (b) fluid accumulation 


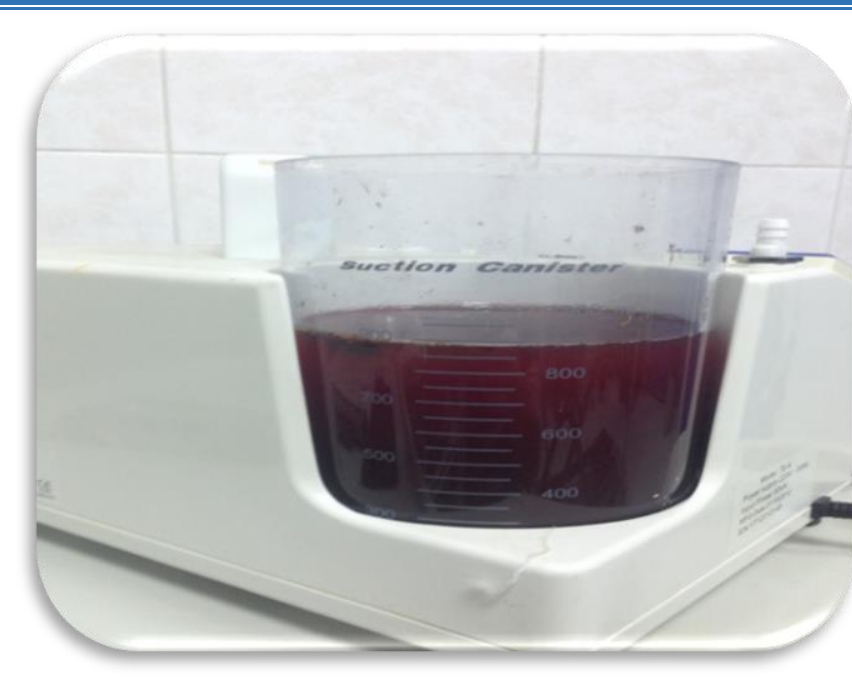

Figure 3. Intraabdominal fluid aspirated at the operation

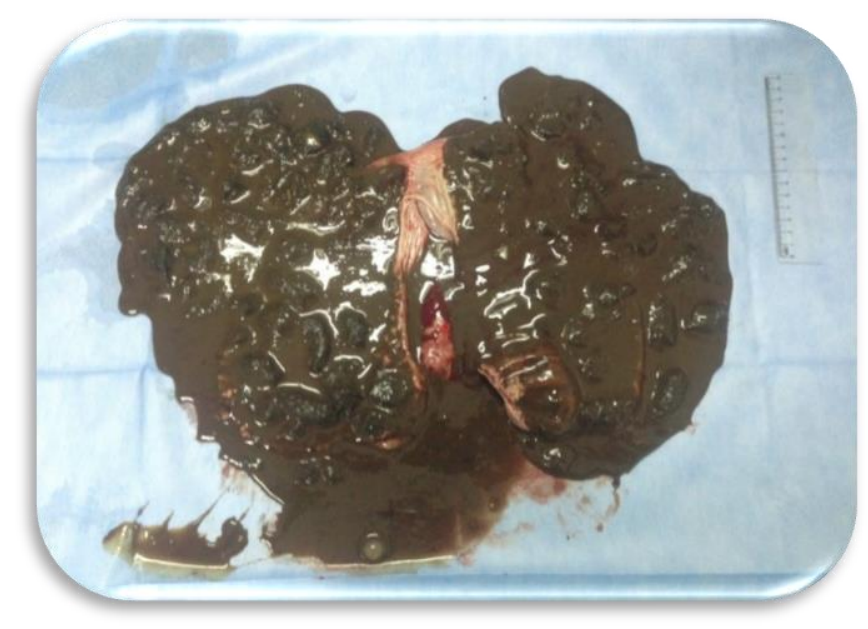

Figure 4. Bone and fur debris after incision of uterus

400.000 IU penicillin (Iecilline ${ }^{\circledR}$; IE Ulagay) was administered intramuscularly for seven days postoperatively. A protective Elizabethan collar was placed. She recovered uneventfully following a week after surgery. There was no complication during the six months of postoperative stage.

\section{DISCUSSION}

The estimation of parturition date by using different methods (detection of LH peak, recording of the estrus and mating dates, fetal biometry etc.), and also fetal monitoring plays an important role on the diagnosis and early treatment of some perinatal problems in dogs. Regarding to the various outcomes of fetal death, these examination results are very supportive on the optimal assessment of maternal situation, but there were very limited records in our case. Besides, it was not easy to find mutual features between this case and previous reports having various history and symptoms.

Despite the fact that the interaction between fetal maceration cases and prolonged pregnancies caused by progestin (González-Domínguez and MaldonadoEstrada, 2006) and hCG injections (Urhausen et al., 2009) are well known, there was no progesterone application in anamnesis. Moreover, other specific disorder like ectopic fetal maceration cases due to excessive oxytocin (Sagar et al., 2017), external trauma (Jackson, 2004; Fasulkov et al., 2014), and any infectious diseases haven't been stated by owner. Therefore, the actual reason of the fetal loss could not be determined in this case.

There have been several clinical reports about intra/extra uterine fluid accumulation following fetal death having no evident effect on the mother's general condition (Serin and Parın, 2009; GonzálezDomínguez et al., 2010; Fasulkov et al., 2014). In those reports, it can be considered that the vaginal drainage of the fetal debris could help preventing maternal sepsis (Serin and Parın, 2009; GonzálezDomínguez et al., 2010). Also, another ectopic fetal maceration case had been diagnosed much earlier (Fasulkov et al., 2014) than our case. Additionally, fetal maceration cases are characterized by full odor vaginal discharge and septicemia findings in various degrees (England, 1998; Johnston et al., 2001). Bodh et al., (2014) observed foul and fetoid discharges from the vulva of animals with fetal maceration. Unlike those typical symptoms in literature, the vaginal discharge was not seen due to closed cervical canal, and also her loss of appetite was detected only in the last week. Uterine distention, and leukocytosis related to chronic infection revealed the fetal maceration followed by ultrasonographic examination and laboratory analysis. Although a number of nonspecific bacteria, including Escherichia coli, Streptococcus, Proteus and Pseudomonas have been identified in many cases of fetal maceration (England, 
1998), odorless uterine contents of this case was considered as no need for bacterial cultivation. Therefore, no microbiological examination was performed.

As a conclusion, veterinarians should perform regular examinations on pregnant dogs regarding various disorders affecting mothers' general health and future fertility, even if they do not show any pathological signs. By using ultrasonography and other necessary interventions during feto-maternal monitoring, early and accurate treatment can be performed in related cases.

\section{ACKNOWLEDGEMENTS}

This article is presented at the "2nd International Congress on Advances in Veterinary Sciences \& Technics (ICAVST)-October 4-8, 2017 Skopje / MACEDONIA".

\section{REFERENCES}

Bodh, D., Gugjoo, MB., Rafee, M.A., Singh, K. (2014). Uterine rupture and fetal maceration in an indian mongrel bitch. Journal of Advanced Veterinary Research, 1(4), 49-52.

England, G. (1998). Pregnancy diagnosis, abnormalities of pregnancy and pregnancy termination. In: England G, Harvey M (ed's), Manual of Small Animal Reproduction and Neonatology. BSAVA Manuals, Hampshire, 118-119.

Fasulkov, I., Atanasov, A., Antonov, A. (2014). A Clinical case of foetal maceration and posttraumatic uterine rupture in a bitch. Istanbul Univ Vet Fak Derg, 40(2), 261-269.

Gill, M.A. (2001). Perinatal and late neonatal mortality in the dog. PhD thesis, The University of Sydney, 50-51.

González-Domínguez, M.S., Maldonado-Estrada, J.G. (2006). Prolonged pregnancy associated to an inappropriate medroxiprogesterone acetate prescription in a bitch: Is rational and ethics the use of exogenous progestin in the bitch? Rev. Colomb. Cien. Pecuarias, $19,442-450$.

González-Domínguez, M.S., Hernandez, C.A., Maldonado-Estrada, J.G. (2010). Protective compromise of great omentum in an asymptomatic uterine rupture in a bitch: a case report. Rev. Colomb. Cien. Pecuarias, 23, 369-376.
Jackson, P.G.G. (2004). Normal birth. In: Jackson PGG (Ed), Handbook of Veterinary Obstetrics. 2nd ed. Philadelphia, W.B. Saunders Company, 1-12.

Johnston, S.D., Kusritz, M.V.R., Olson, P.N.S. (2001). Canine pregnancy. In: Johnston SD (Ed), Canine and Feline Theriogenology. Philadelphia, W.B. Saunders, 88.

Jones, T.J., Hunt, R.D., King, N.W. (1997). Genital system. In: Veterinary Pathology. Lippincott William and Wilkins, Baltimore, 1149-1222.

Linda-Forsberg, C., and Eneroth, A. (1998). Parturition. In: Simpson GM (Ed), Manual of Small Animal Reproduction and Neonatology. Gloucester, UK: British Small Animal Veterinary Association 1998, 127-142.

Max, A., Jurka, P., Bartyzel, B.J., Grzegrzolka, B. (2015). Foetal mortality in dogs and cats not related to spontaneous abortions. Folia Pomer Univ Technol Stetin Agric Aliment Pisc Zootech, 316(33), 81-88.

Romagnoli, S. Complications in canine pregnancy and their clinical approach. Proceedings of the Veterinary Sciences Congress, Oeiras, 10-12 Out 2002, 159-162.

Sagar, P.V., Kumar, P.R., Raghunath, M. (2017). Ectopic fetal maceration in a Labrador bitch. Livestock Science, 8, 8-10.

Serin, G., Parm, U. (2009). Recurrent vaginal discharge causing by retained foetal bones in a bitch: a case report. Vet Med-Czech, 54(6), 287-290.

Tønnessen, R., Borge, K.S., Nødtvedt, A., Indrebø, A. (2012). Canine perinatal mortality: A cohort study of 224 breeds. Theriogenology, 77, 1788-1801. Doi: 10.1016/j.theriogenology.2011.12.023

Urhausen, C., Schöne, J., Meyer-Lindenberg, A., Günzel-Apel, A.R. (2009). An extraordinary iatrogenic prolongation of pregnancy in a German Shepherd Dog. A case report. 6th EVSSAR Annual Symposium, Wrocław, 79. 